DOI:10.24193/tras.58E.5

Published First Online: 10/21/2019

\section{FACTORS INFLUENCING \\ THE PROPENSITY TO CONTRACT \\ OUT HEALTH AND HUMAN \\ SERVICES IN RESPONSE TO \\ GOVERNMENT CUTBACKS: \\ EVIDENCE FROM US COUNTIES}

\author{
Min-Hyu KIM
}

\author{
Min-Hyu KIM \\ Assistant Professor, School of Public Affairs, \\ Arizona State University, Arizona, United States; \\ The Hainan University-Arizona State University \\ Joint International Tourism College, \\ Hainan University, Hainan Province, China \\ E-mail: mkim218@asu.edu
}

budget cutbacks. Possible effects of budget cutbacks on the propensity to contract out have been discussed repeatedly; however, empirical evaluations are lacking. This study tests the contingency theory regarding the main factors that influence the propensity to contract out health and human services in response to fiscal stress: cutback levels, training and development, political factors, diversity as a goal, and the role of unions. The empirical analyses used a nationwide survey of health and human services directors in United States (U.S.) county governments, merged from different sources. The findings suggested that managers' perceptions of cutback levels are a vital predictor of the propensity to contract out health and human services, and multiple factors have varied influences on their decision to do so in cutback situations. Implications for effective contracting strategies to maintain health and human service delivery, as well as preserving a balanced budget, are discussed.

Keywords: contracting out, cutback management, local government, health and human services. 


\section{Introduction}

Government finances remain vulnerable due to the cyclical peaks and troughs in the national economy as well as the frequent fundamental changes in public revenue. Since the end of 2009, the global economy has undergone chronic fiscal shortfalls because of transitory economic shocks and structural budget deficits resulting from the weak economy (Feaster et al., 2011), to which the U.S. is no exception. Fiscal stress 'financial pressure on a government from factors such as revenue shortfalls, as well as taxing and spending limitations' - force government agencies to stave off fiscal imbalances by downsizing and other strategies (Bowman and Kearney, 2017, p. 362). Policymakers search persistently for solutions when recessionary clouds hover over the financial horizon. Government agencies contend with more stringent budgetary constraints than for-profit businesses when they are hit hard by significant fiscal challenges. Governments at all levels respond by cutting spending since fiscal stress remains the most serious threat, even for the most capable agencies.

Under these circumstances, government agencies have traditionally contracted out services as one strategy to manage budget cutbacks (López-Hernández et al., 2018; Sun, 2010; Chen, 2013; West and Condrey, 2010). The underlying assumption was that contracting out is one of the most effective interventions to curb expenditures to buffer the repercussions of pressing fiscal problems (Ladi and Tsarouhas, 2014). For example, the U.S. federal government spent over 500 billion U.S. dollars for contracted products and services in 2012 (Government Accountability Office, 2017). Yet current research offers little systematic insight into whether and how this relationship between fiscal stress and the propensity to contract out might vary by sector. Do efforts to contract out appeal differently to nonprofits, private firms, and other government agencies? Several theoretical frameworks have been used to model the propensity to contract out (Niskanen, 1971; Zafra-Gómez et al., 2016; Williamson, 1981; Brown and Potoski, 2003). These theories rest on the assumption that government agencies have adequate revenue to cover expenses. However, what if government agencies experience fiscal stress during an economic downturn?

This study was designed to add to this literature by analyzing the influence of theory-based factors that may explain the propensity to contract out health and human services to different vendors in the context of U.S. county-level agencies. We distinguished between three service delivery modes (nonprofit organizations, private firms and other government agencies). This study examines empirically why some government agencies have a greater likelihood to contract out in response to budget cutbacks, and makes an original and significant contribution to our understanding of the factors that influence the propensity to contract out. The next section provides a review of the previous literature and is followed by a discussion of the hypotheses, methods, and results, concluding with a discussion of the implications for research and practice. 


\section{The relationship between changes in resource levels and contracting out: a contingency approach}

Contingency theory suggests that government agencies implement contracting out as a cutback management strategy (Levine et al., 1981; Sun, 2010; Jimenez, 2017; Chen, 2013). Contingency theorists (Burns and Stalker, 1961; Galbraith, 1977; Lawrence and Lorsch, 1967) have argued that different service delivery modes are appropriate in different decision contexts. Specifically, the choice of sector with which to contract, like other administrative functions, involves values and choices, i.e., uncertainty about goals, means, and the contexts within which decisions are made. Fiscal stress is a critical example of external environments in contingency approaches, because lack of funding is one of the most difficult crises that organizations face.

Levine et al. (1981) demonstrated that U.S. local governments contract out services depending on the interactions of several factors: (1) changes in financial resource levels, (2) the formal authority structure, (3) interest group structure, and (4) subsequent outcomes of these strategies. This study focuses on three factors in this model because the combined effects of changes in resource level, formal authority, and interest groups influence the local governments' contracting out strategies (Levine et al., 1981; Chen, 2013).

\subsection{Changes in resource levels}

Empirical research has demonstrated the positive effects of fiscal stress on the propensity to contract out (Brown et al., 2008; Dijkgraaf et al., 2003; Ferris and Graddy, 1988). For example, Brudney et al. (2005) found that U.S. state agencies experiencing higher levels of fiscal need or demand for expenditures are more likely to contract out a larger percentage of their budgets. $\mathrm{Lu}$ (2013) also found that U.S. state governments that face greater fiscal difficulty are more likely to contract out their human services to nonprofits.

We hypothesize that managers' perceptions of cutbacks and actual fiscal stress are associated positively with the propensity to contract out (Brown et al., 2008; Dijkgraaf et al., 2003; Ferris and Graddy, 1988). The purpose of this study is to examine the relationship between cutback levels and local governments' propensity to contract out fully by exploring how self-reported and objective measures of fiscal condition affect contracting decisions. The outcome variable is the propensity to contract out, and the key predictors are managers' perceptions and objective measures of fiscal stress.

Hypothesis 1-A: There is a positive relationship between managers' perceptions of cutbacks and the propensity to contract out.

Hypothesis 1-B: Counties facing heavier fiscal stress are more likely to contract out.

\subsection{Training and development}

Training and development include, among other things, mentoring, cross-training, and professional development (Pynes, 2003). These programs involve classroom activities as well as practical on-the-job training by current employees. Most coun- 
ty-level government agencies try to implement their professional training and development activities, because these activities provide the basic training for their newly-hired staff that otherwise could not be provided.

Advocates of contracting out argue that there are cost benefits associated with contracting out training and development units (Hall, 2000; Domberger, 1998). If training is one of the first aspects to be cut when faced with fiscal stress (Lewis, 1988), the local governments that train and develop their employees are likely to contract out more as well, in the hopes that contracting out would alleviate fiscal pressures. Thus, public managers under new challenges such as budget cuts are more likely to contract out their training and development units for fiscal reasons. As a result, public managers who focus on training and development are more likely to contract out services in response to cutbacks. Therefore, we hypothesize:

Hypothesis 2: There is a positive relationship between the importance a local government places on training and development and the propensity to contract out.

\subsection{Political factors}

According to Levine et al. (1981), county directors perceive state and county political leadership to be consequential factors, because the pressure of cutting back trickles down from state and county governments. Thus, county directors' perceptions of state and county political leadership influence their decision to contract out. However, public managers may perceive the effects of county political leadership differently because the majority of counties do not have elected executives. Therefore, we hypothesize an open relationship between county political leadership and the propensity to contract out.

Hypothesis 3-A: There is a positive relationship between state political leadership and the propensity to contract out.

Hypothesis 3-B: There is a relationship between county political leadership and the propensity to contract out.

While Republican or Democratic state and county political leadership plays an important role in the propensity to contract out, the relationship is rather complex. At a conceptual level, conservative political leadership traditionally has valued limited government, often criticized government expansion, and viewed government programs as a potential threat to individual, county, or state liberty (Dubin and Navarro, 1988; Walls et al., 2005). However, as contracting out has become a more popular option, it has transcended party boundaries, and interests in contracting out can no longer be viewed as solely conservative agendas. Therefore, this study hypothesizes an open relationship between the state legislators' parties representing the county and the propensity to contract out.

Hypothesis 3-C: There is a relationship between state legislators' parties representing counties and the propensity to contract out. 
Previous literature has argued that the governors' political party has an important influence on the local-level decision making (Warner and Hebdon, 2001; Williams, 1986). Because both Democratic and Republican governors care about cost savings, politics can work both ways in the influence of governors' political parties on the contracting decision. Therefore, the study also hypothesizes an open relationship between governors' parties and the propensity to contract out.

Hypothesis 3-D: There is a relationship between governors' parties and the propensity to contract out.

\subsection{Diversity as a goal}

Previous studies warned about the negative effects contracting out reform efforts could have on diversity efforts (Radin, 2012). For example, Stein (1994) found that contracting out in response to cutbacks tends to disproportionately harm African American employees. Diversity in this study focuses on fairness in the employee composition and work practices in government agencies, especially regarding race, ethnicity, and gender. We predict that as public managers place more importance on diversity, they are less likely to contract out in response to cutbacks. This is because contracting out in response to cutbacks may inhibit diversity efforts (Piatak, 2018).

Hypothesis 4: There is a negative relationship between the level of importance a local government places on diversity management and the propensity to contract out.

\subsection{The role of unions}

Unionization often is considered to be an obstacle to contracting out in local governments. At a conceptual level, the contingency theory suggests that stronger unions are more active and effective in protecting departments and programs from austerity (Levine et al., 1981, p. 42). For example, several empirical studies have addressed that the fear of layoffs has led labor unions to oppose contracting out (DeHoog and Salamon, 2002; Fernandez et al., 2002). In terms of service delivery modes, Warner and Hebdon (2001) documented a negative relationship between unionization and contracting out services either to private firms or other municipalities, while Kim and Warner (2016) reported that unionization has a negative effect on inter-municipal cooperation, but is not associated with private contracting. In this study, the role of unions is used as a variable measuring the importance that public managers place upon unions when they make contracting decisions. Therefore, we hypothesize:

Hypothesis 5: There is a negative relationship between the level of importance a local government places on the role of unions and the propensity to contract out. 


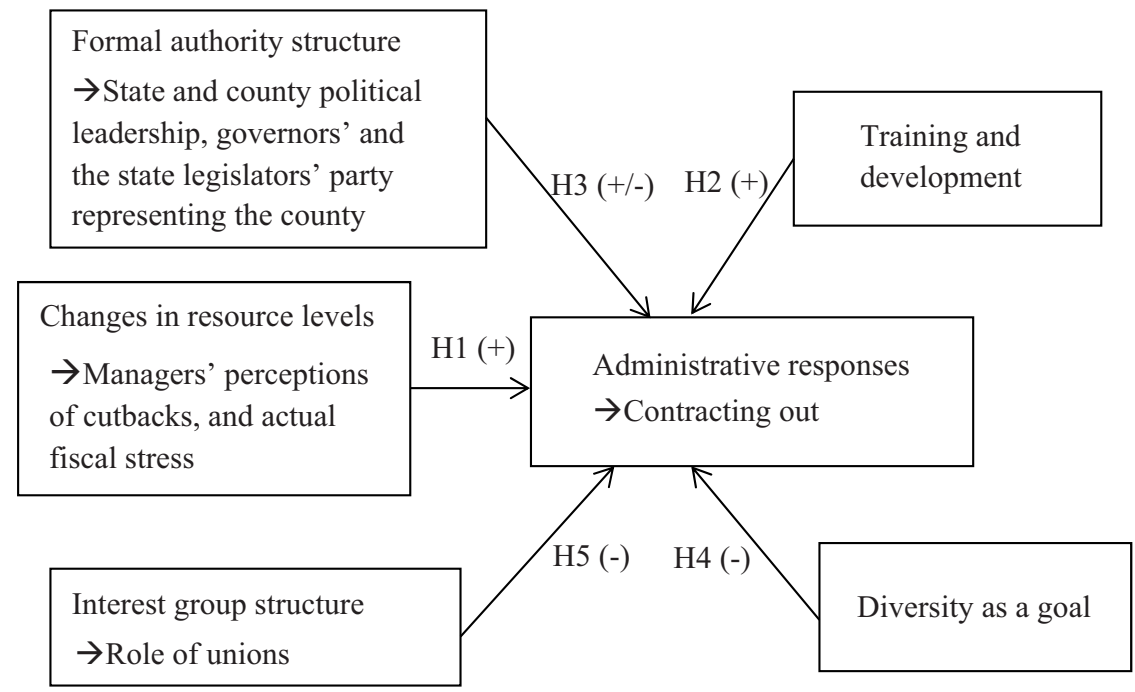

Figure 1: Contingency framework

\section{Data and methods}

The research sample chosen for this study is health and human services directors for the following reasons. First, health and human services agencies have long led civilian contracting agencies, and these agencies have allocated 20.9 trillion U.S. dollars to contracting obligations in $2014^{1}$. Second, health and human services are major areas of government that serve needy populations, such as aged or disabled citizens. Lastly, the health and human services sector has experienced one of the most severe budget cutbacks during the last five years (McDonough, 2013), and the budget sequestration in 2013 has had adverse effects on U.S. health and human services delivery. Therefore, conducting research on such agencies helps us understand better the way in which public managers contract out services to cope with cutbacks.

We use data from a study of health and human services directors in U.S. county governments with populations of at least 10,000 citizens covering 50 states and the District of Columbia. A multistage probability sampling of the agencies in county governments is used for this survey. A list was developed from U.S. Census Bureau Data, and a total of 1,221 agencies were generated as the final sample ${ }^{2}$. To distribute a self-administered survey, email addresses of the respondents were obtained from each county government's webpage.

1 Retrieved from http://www.ncmahq.org/docs/default-source/default-document-library/pdfs/exe c15---ncma-annualreview-of-government-contracting-2015-edition (accessed on August 26, 2017).

2 1,221 counties were the final sample of this study based on the following: first, in 2016, there were 1,899 US counties with populations of at least 10,000 citizens; second, there were 678 counties that did not have their government websites or did not have information about health and human services agencies, and third, 1,221 counties were the final sample of this study. 
An online survey instrument was used in this study. The survey items were generated from previous survey instruments (Jimenez, 2013; Hajnal, 2013; Sun, 2010). The questionnaire was administered online in September and October 2016. This study used multiple modes of communication to yield higher response rates (Dillman et al., 2014). An overall response rate was 33\%, which is 381 complete responses among the 1,161 that received the survey (60 emails bounced back).

Table 1: Respondents' characteristics and organizational contexts

\begin{tabular}{|c|c|c|c|}
\hline & Variable & Freq. & Percent \\
\hline \multirow{2}{*}{ Governors' party } & Republican & 264 & 69.29 \\
\hline & Democrat & 117 & 30.71 \\
\hline \multirow{2}{*}{$\begin{array}{l}\text { The state legislatures' party } \\
\text { representing the county }\end{array}$} & Republican & 259 & 67.98 \\
\hline & Democrat & 122 & 32.02 \\
\hline \multirow{7}{*}{ Current position } & Commissioner & 17 & 4.46 \\
\hline & Director & 218 & 57.22 \\
\hline & Deputy Director & 16 & 4.20 \\
\hline & County Administrator & 40 & 10.50 \\
\hline & County Manager & 15 & 3.94 \\
\hline & Program Manager & 32 & 8.40 \\
\hline & Other & 43 & 11.29 \\
\hline \multirow{2}{*}{ Minority } & Non-minority & 336 & 88.19 \\
\hline & Minority & 45 & 11.81 \\
\hline \multirow{2}{*}{ Gender } & Male & 109 & 28.61 \\
\hline & Female & 272 & 71.39 \\
\hline \multirow{2}{*}{ Autonomy } & Counties with appointed county administrators & 304 & 79.79 \\
\hline & Counties with elected county executives & 77 & 20.21 \\
\hline \multirow{2}{*}{ Health agency } & Others & 191 & 50.13 \\
\hline & Health & 190 & 49.87 \\
\hline \multirow{6}{*}{ Population } & 10,000 to 24,999 & 47 & 12.34 \\
\hline & 25,000 to 49,999 & 69 & 18.11 \\
\hline & 50,000 to 99,999 & 104 & 27.30 \\
\hline & 100,000 to 249,999 & 83 & 21.78 \\
\hline & 250,000 to 499,999 & 33 & 8.66 \\
\hline & 500,000 or more & 45 & 11.81 \\
\hline \multirow{4}{*}{ Region } & Northeast & 52 & 13.65 \\
\hline & Midwest & 151 & 39.63 \\
\hline & South & 128 & 33.60 \\
\hline & West & 50 & 13.12 \\
\hline Number of obs. & & 381 & 100.00 \\
\hline
\end{tabular}

To measure the dependent variable, the propensity to contract out services, respondents were asked 'In the last five years, how often has your agency contracted out services to the following in response to budget cutbacks? Read each item; Code 
one for each: (1) nonprofit agencies; (2) private companies, or (3) other government agencies.' Respondents could indicate on a 1-3 scale, in which 1 indicates 'never', 2 'a few times' and 3 'more than a few times'3 (Florida Survey Research Center, 2012).

Table 2: Respondents' descriptions of budget cutbacks in the last five years

\begin{tabular}{lrc}
\hline & Freq. & Percent \\
\hline No budget cutbacks & 50 & 13.12 \\
Modest budget cutbacks & 217 & 56.96 \\
Substantial budget cutbacks & 114 & 29.92 \\
Total & 381 & 100.00 \\
\hline
\end{tabular}

With respect to Hypothesis 1-B, the study collected the fiscal stress data from each county government website ${ }^{4}$. To date, there is no widely accepted measurement of fiscal stress (Alm et al., 1993; Aronson and Hilley, 2010; Bahl, 1984). We use operating solvency to indicate fiscal stress (Stone et al., 2015), because the focus is on assessing fiscal condition within the time frame. County fiscal stress in 2014 is computed as follows (Stone et al., 2015):

$$
\text { Fiscal stress }(\%)=\frac{\text { total county revenue-total county expenditure }}{\text { total county revenue }} \times 100
$$

A negative value indicated greater fiscal stress. According to Table 3, the average size of health and human services budgets was 157 million U.S. dollars in fiscal year $2014^{5}$.

Table 3: Descriptive statistics of continuous variables

\begin{tabular}{lcrrrr}
\hline \multicolumn{1}{c}{ Variable } & Obs. & \multicolumn{1}{c}{ Mean } & \multicolumn{1}{c}{ SD } & \multicolumn{1}{c}{ Min } & \multicolumn{1}{c}{ Max } \\
\hline Fiscal Stress (\%) & 381 & -0.9 & 11.2 & -43.2 & 60.5 \\
\hline Health and Human Services Budgets & 381 & $1.57 \mathrm{E}+08$ & $1.00 \mathrm{E}+09$ & 5100 & $1.11 \mathrm{E}+10$ \\
Per Capita Income & 381 & 43,999 & 13,277 & 25,003 & 194,861 \\
\hline
\end{tabular}

In terms of the second hypothesis, we construct an index variable that captures the importance placed on training and development activities by local government directors (Goodman et al., 2013). The training and development index is the average value of responses to all three items - professional development, cross-training, and mentoring - in each county. According to Appendix B, the Cronbach's $\alpha$ is 0.91 , which represents a high degree of internal reliability.

3 This study used a 1-3 scale based on pilot testing of 17 health and human services directors. Initially, a 1-7 scale was planned, but health and human services directors were able to understand the 1-3 scale more easily than the 1-7 scale.

4 When the county budget information for fiscal year 2014 was unavailable on the websites, the county treasurers' offices were contacted to obtain the data.

5 This information was obtained from copies of each county's Comprehensive Annual Financial Reports (CAFR) for the fiscal year ending June 30, 2015. 
With respect to the third set of hypotheses, the survey asks local government directors to rate the importance of state and county political leadership. The survey item is measured on a scale of 1-3 in which 'not important' is coded as 1, 'somewhat important' as 2, and 'very important' as 3 (Florida Survey Research Center, 2012). In terms of governors' parties, this study used a dummy variable to indicate whether 2014 was a Democratic or Republican gubernatorial term ( $1=$ Democratic and $0=$ Republican $)$. For the state legislators' party representing the county, a dummy variable is used to indicate whether a majority of the state legislators' party representing the county was Democratic or Republican (coded 1 for Democratic, and 0 for Republican).

In terms of the fourth hypothesis, the survey asks local government supervisors to rate the importance of diversity as a management goal between 2012 and 2016 (Goodman et al., 2013). The survey item is measured on a scale of 1-3 that ranges from 'not important' (1) to 'very important' (3).

Regarding the final hypothesis, the role of unions is measured on a scale of 1-3, in which 'not important' is coded as 1, 'somewhat important' as 2 , and 'very important' as 3 (Goodman et al., 2013).

Several control variables are used in the analyses to isolate the effects of the influential factors on contracting decision. First, the sociodemographic variables are economic condition, population, and a regional indicator. Second, the model also includes a dummy variable indicating whether the county has elected or appointed executives. Lastly, a dummy variable is used to control whether the agencies are health or human services agencies. Measurement of these variables is shown in Appendix A.

This study used an ordered logit model, because the dependent variable, the propensity to contract out, is an ordinal variable. For model diagnostics, the Brant test is used to test the parallel coefficient assumption. The result of the Brant test showed that the parallel assumption is not violated significantly $(\mathrm{p}>0.05)$.

\section{Findings}

Table 4 shows the three-way tabulation of the propensity to contract out services to multiple sectors. With respect to frequencies, health and human services agencies were found to rely heavily on nonprofit contracting, while contracting out to private firms and other government agencies ranked second and third, respectively. Further, regarding multiplicity, government agencies using private contracting are more likely to contract out to multiple sectors (86\%), perhaps because those agencies relying on private contracting turn to nonprofits or other government agencies because private contracting is the most expensive option. 
Table 4: Propensity to contract out services to multiple sectors

\begin{tabular}{lrrrr}
\hline & $\begin{array}{c}\text { Contracting out to } \\
\text { all three sectors }\end{array}$ & $\begin{array}{c}\text { Contracting out } \\
\text { to two sectors }\end{array}$ & $\begin{array}{c}\text { Contracting out } \\
\text { only to one sector }\end{array}$ & Total \\
\hline Nonprofit organizations & 70 & 66 & 52 & 188 \\
& $37.2 \%$ & $35.1 \%$ & $27.7 \%$ & $100.0 \%$ \\
Private firms & 70 & 48 & 19 & 137 \\
Other government & $51.1 \%$ & $35.0 \%$ & $13.9 \%$ & $100.0 \%$ \\
agencies & 70 & 34 & 20 & 124 \\
\hline
\end{tabular}

Note: Contracting out to all three sectors refers to those agencies that contract out health and human services to all three sectors (nonprofit/private/other government agencies). Contracting out to two sectors refers to those agencies that contract out only to two sectors (nonprofit/private, private/other government agencies, or nonprofit/other government agencies). Contracting out only to one sector refers to those agencies that contract out only to nonprofit, private, or other government agencies.

Table 5 shows the results of the ordered logit regression of the propensity to contract out services to three sectors (nonprofits, private firms, and other government agencies).

The perceptions of cutback levels are statistically significant for all three models $(p<0.05)$. Respondents who perceive greater cutbacks are more likely to contract out services to nonprofits, private firms, and other government agencies. This is consistent with the previous literature that the probability of contracting out increases when financial stress is greater (Brown et al., 2008; Dijkgraaf et al., 2003; Ferris and Graddy, 1988). The objective fiscal stress measure seems to have little to do with contracting decisions as no significant results were found.

In examining the importance of the training and development activities, the odds of private contracting by public managers who place more importance on the training and development activities are more than double the odds of those who place less importance on these activities. No significant differences were found for the propensity to contract out services to nonprofits and other government agencies.

With respect to political factors, public managers who think state political leadership to be important are more likely to turn to private contracting, but those who place more importance on county political leadership are less likely to do so. This inconsistency reflects the fact that public managers seem to perceive that state political leadership is more important, because county-level agencies should consult with state governments in making contracting decisions. For governors' and the state legislators' party representing the county, no significant results were found for Republican or Democratic political leadership.

Regarding the importance placed on diversity as a goal, the more importance public managers place on diversity, the less likely they are to contract out services to other government agencies. No significant results were found for private or nonprofit contracting. 
Lastly, in terms of the role of unions, no significant results were found, perhaps because civil servants in health and human services agencies are professional workers, such as doctors, nurses, laboratory technicians, and clinical social workers who tend to be less likely to organize unions. Union officials face negative images and stereotypes of unions held by human services professionals (Scanlon and Harding, 2005). Table 6 below provides the full list of supported and unsupported hypotheses at the level of statistical significance $(\mathrm{p}<0.10)$.

Table 5: Ordered logistic regression analyses of the factors influencing the propensity to contract out in response to cutbacks (Odds Ratios)

\begin{tabular}{lccc}
\hline & Nonprofits & Private firms & $\begin{array}{c}\text { Other Government } \\
\text { Agencies }\end{array}$ \\
\hline Cutbacks & $1.466^{* *}$ & $1.556^{* * *}$ & $2.041^{* * *}$ \\
Fiscal stress & 1.007 & 0.992 & 0.988 \\
\hline Training \& development & 1.273 & $2.129^{* *}$ & 1.547 \\
\hline County political leadership & 1.087 & $0.699^{* *}$ & 0.827 \\
\hline State political leadership & 1.182 & $1.379^{* *}$ & 1.202 \\
\hline State legislators' party representing the county (Democrat=1) & 1.074 & 1.239 & 1.207 \\
\hline Governors' party (Democrat=1) & 1.390 & 1.326 & 1.010 \\
\hline Diversity as a goal & 0.971 & 0.978 & $0.744^{*}$ \\
\hline Role of unions & 0.927 & 1.165 & 0.851 \\
\hline Control variables & & & \\
\hline Elected executive (Elected official=1) & $1.554^{*}$ & 1.135 & 0.729 \\
In(Per Capital Income) & 1.139 & 1.226 & $1.931^{*}$ \\
\hline Health (Health Agency=1) & 0.783 & $0.721^{*}$ & 0.881 \\
\hline Population & $1.209^{* * *}$ & 1.041 & 1.017 \\
\hline Region & & & \\
\hline Northeast & 1.012 & 0.547 & $0.343^{* *}$ \\
\hline Midwest & 0.889 & 0.664 & 0.783 \\
\hline South & $0.582^{*}$ & 1.118 & 0.788 \\
\hline /cut1 & 3.693 & 5.685 & 9.216 \\
\hline cut2 & 6.604 & 8.699 & 12.378 \\
\hline Observations & 386 & 387 & 383 \\
\hline Likelihood ratio test (X2) & $28.99^{* *}$ & $30.26^{* *}$ & $28.01^{* *}$ \\
\hline Pseudo R2 & 0.044 & 0.053 & 0.053 \\
\hline
\end{tabular}

Note: Reference region $=$ West. ${ }^{*} p<0.10,{ }^{* *} p<0.05,{ }^{* * *} p<0.01$ 
Table 6: List of supported and unsupported hypotheses

\begin{tabular}{|c|c|c|}
\hline & Hypotheses & Results \\
\hline $1-\mathrm{A}$ & $\begin{array}{l}\text { There is a positive relationship between managers' perceptions of cutbacks and the pro- } \\
\text { pensity to contract out. }\end{array}$ & Supported \\
\hline $1-B$ & Counties that face heavier fiscal stress are more likely to contract out. & Unsupported \\
\hline 2 & $\begin{array}{l}\text { There is a positive relationship between the importance a local government places on } \\
\text { training and development and the propensity to contract out. }\end{array}$ & Partially supported \\
\hline $3-A$ & $\begin{array}{l}\text { There is a positive relationship between state political leadership and the propensity to } \\
\text { contract out. }\end{array}$ & Partially supported \\
\hline 3-B & $\begin{array}{l}\text { There is a relationship between county political leadership and the propensity to contract } \\
\text { out. }\end{array}$ & Partially supported \\
\hline $3-\mathrm{C}$ & $\begin{array}{l}\text { There is a relationship between state legislators' party representing the county and the } \\
\text { propensity to contract out. }\end{array}$ & Unsupported \\
\hline $3-D$ & There is a relationship between governors' party and the propensity to contract out. & Unsupported \\
\hline 4 & $\begin{array}{l}\text { There is a negative relationship between the level of importance a local government plac- } \\
\text { es on diversity management and the propensity to contract out. }\end{array}$ & Partially supported \\
\hline 5 & $\begin{array}{l}\text { There is a negative relationship between the level of importance a local government plac- } \\
\text { es on the role of unions and the propensity to contract out. }\end{array}$ & Unsupported \\
\hline
\end{tabular}

\section{Discussion and conclusion}

Drawing on the cutback management literature (Chen, 2013; Jimenez, 2017; Sun, 2010), this study finds that governments use contracting out as a strategy to cope with cutbacks. The study then identifies the main factors that account for the propensity to contract out: cutback levels, training and development, political factors, diversity as a goal, and the role of unions.

The objective measure of fiscal stress seems to have little to do with contracting decisions as we found no significant evidence of the effects. Importantly, these findings do not necessarily disprove the contingency hypotheses, as this discrepancy between the perception and the fiscal stress must be examined and interpreted carefully. One way to interpret this discrepancy is the lack of the specific agency-level fiscal stress level data and a possible gap between reality and managers' perceptions. More specifically, in 2014, county governments, on average, had nearly balanced budgets. However, there still can be implicit budget deficits, regardless of the balanced budget letters. Thirty-seven states and Puerto Rico use the state balanced budget restriction that the budget must be balanced at the end of a fiscal year or biennium, so that no deficit can be carried forward (Fisher, 2004) ${ }^{6}$. Thus, many states use the accounting gimmicks at the end of successive fiscal years, so that the implicit budget deficits will quickly snowball. In early 2013, this accumulated deficit precipitated a fiscal crisis, as the city of Detroit was effectively excluded from credit markets. Therefore, it is possible that the implicit budget deficit may still exist even though the balanced budget is announced on county government websites.

6 See Fisher (2004) for the list of states. 
This study also finds that respondents who place a greater emphasis on training and development are more progressive in their implementation of private contracting, perhaps because the cost of staff training and development cannot be underestimated, as it is one of the most invaluable assets a local government has at its disposal. As government organizations train and develop their employees to ensure continuity of services and mission implementation under budget cuts and reduction-in-staff, contracting out is seen as a cost-cutting strategy if a third party can effectively deliver services better and more cheaply than the public agency and its employees. Thus, public managers who focus on training and development will turn to the opinion of outside providers because contracting out often is viewed as a way to save tax dollars, reduce the public payrolls, and minimize government expenditures (Pynes, 2008).

Public managers who think managing diversity to be important are less likely to contract out services to other government agencies. One interpretation of the findings is that public managers under resource constraints may be concerned that contracting out in response to cutbacks may continue to impede workforce diversity in their organizations. For example, Piatak (2018) found that African-American employees are more likely to lose their jobs during the fiscal retrenchment period. Future research along these lines are needed.

The results reported here have implications for both scholars and public managers. In terms of theoretical contributions, this study advances prior research, because we developed Levine et al.'s (1981) contingency framework further by adding the following to the framework: training and development, as well as diversity as a goal. This study showed that training and development, as well as diversity as a goal need to be integrated into contracting out practices. The findings indicate that public managers who perceive the importance of training and development are more likely to contract out to private firms, but those who value diversity as a goal are less likely to contract out to other government agencies. The framework provided here also might be used to conduct empirical studies of other cutback strategies implemented by governments faced with economic downturns.

With respect to practical implications, first, state and local governments should consider conducting comprehensive cost-benefit analyses in advance before they contract out services to outside vendors. When governments forgo their due diligence and choose ill-equipped contractors whose progress they fail to monitor, contracting deals can have costly consequences. Thus, it is important to examine the cost-effectiveness of hiring third party vendors before government agencies contract out services.

Second, state and local governments might consider establishing permanent and centralized entities to manage and oversee their operations, from project analyses to selecting vendors in contracting and procurement. Health and human services agencies contract out services to the third parties that have limited controls over the root cause of the problem. One problem is that some of the outside contractors are concerned with cost effectiveness, and pay less attention to public values and citizens 
they serve. Therefore, one way for contracting out to work is to set up specialized agencies within governments to monitor the operations.

In summary, this study encourages academics and practitioners to investigate further the multifaceted relations among governments, nonprofits, private vendors, and other public agencies in the fiscal retrenchment process. Future studies should investigate whether contracting out translates into improved policy outcomes, including organizational capacity and balanced budgets.

\section{References:}

1. Alm, J., McKee, M. and Skidmore, M., 'Fiscal Pressure, Tax Competition, and the Introduction of State Lotteries', 1993, National Tax Journal, vol. 46, no. 4, pp. 463-476.

2. Aronson, J.R. and Hilley, J.L., Financing State and Local Governments, Washington, DC: Brookings Institution Press, 2010.

3. Bahl, R.W., Financing State and Local Government in the 1980s, London: Oxford University Press, 1984.

4. Bel, G. and Fageda, X., 'Why Do Local Governments Privatize Public Services? A Survey of Empirical Studies', 2007, Local Government Studies, vol. 33, no. 4, pp. 517-534.

5. Bowman, A.O.M. and Kearney, R.C., State and Local Government, Boston, MA: Cengage Learning, 2017.

6. Brown, T.L. and Potoski, M., 'Transaction Costs and Institutional Explanations for Government Service Production Decisions', 2003, Journal of Public Administration Research and Theory, vol. 13, no. 4, pp. 441-468.

7. Brown, T.L., Potoski, M. and Van Slyke, D.M., 'Changing Modes of Service Delivery: How Past Choices Structure Future Choices', 2008, Environment and Planning C: Politics and Space, vol. 26, no. 1, pp. 127-143.

8. Brudney, J.L., Fernandez, S., Ryu, J.E. and Wright, D.S., 'Exploring and Explaining Contracting Out: Patterns among the American States', 2005, Journal of Public Administration Research and Theory, vol. 15, no. 3, pp. 393-419.

9. Burns, T.E. and Stalker, G.M., The Management of Innovation, London, UK: Tavistock Publications, 1961.

10. Carr, D.L., 'Public Authorities in Governing New Jersey', Galloway, NJ: William J. Hughes Center for Public Policy, 2012, [Online] available at https://pdfs.semanticscholar.org/7f93/f5808aba2ae52c0f3fcc9cd32af261a44740.pdf, accessed on November 15, 2017.

11. Chen, G., Cutback Strategies in State Pension Systems under State Fiscal Stress (unpublished doctoral dissertation), University of Nebraska at Omaha, NE, 2013.

12. DeHoog, R.H. and Salamon, L.M., 'Purchase-of-Service Contracting', in Salamon, L.M. (ed.), The Tools of Government: A Guide to the New Governance, New York, NY: Oxford University Press, 2002, pp. 319-339.

13. Dijkgraaf, E., Gradus, R.H.J.M. and Melenberg, B., 'Contracting out Refuse Collection', 2003, Empirical Economics, vol. 28, no. 3, pp. 553-570.

14. Dillman, D.A., Smyth, J.D. and Christian, L.M., Internet, Phone, Mail, and Mixed-Mode Surveys: The Tailored Design Method, $4^{\text {th }}$ edition, New York, NY: John Wiley \& Sons, 2014. 
15. Domberger, S., The Contracting Organization: A Strategic Guide to Outsourcing, London: Oxford University Press, 1998.

16. Dubin, J.A. and Navarro, P., 'How Markets for Impure Public Goods Organize: The Case of Household Refuse Collection', 1988, Journal of Law, Economics E Organizations, vol. 4, no. 2, pp. 217-241.

17. Feaster, S.W., Schwartz, N.D. and Kuntz, T., 'It's All Connected: A Spectator's Guide to the Euro Crisis', New York Times, October 22, 2011, p. 5.

18. Fernandez, S., Rainey, H.G. and Lowman, C.E., 'Privatization and Its Implications for Human Resources Management', in Riccucci, N.M. (ed.), Public Personnel Management: Current Concerns, Future Challenges, $4^{\text {th }}$ edition, New York, NY: Longman, 2002, pp. 204-224.

19. Ferris, J. and Graddy, E., 'Production Choices for Local Government Services', 1988, Journal of Urban Affairs, vol. 10, no. 3, pp. 273-289.

20. Fisher, R.C., State and Local Public Finance, Glenview, IL: Scott, Foresman and Company, 2004.

21. Florida Survey Research Center, County Administrator Survey, Gainesville, FL: University of Florida, 2012.

22. Galbraith, J.R., Organization Design, Boston, MA: Addison Wesley Publishing Company, 1977.

23. Goodman, D., French, P.E. and Battaglio, R.P., 'Determinants of Local Government Workforce Planning', 2013, The American Review of Public Administration, vol. 45, no. 2, pp. 135-152.

24. Government Accountability Office, 'Contracting Data Analysis: Assessment of Government-wide Trends', United States Government Accountability Office Report to Congressional Addresses, March 2017, [Online] available at https://www.gao.gov/as sets/690/683273.pdf, accessed on September 23, 2019.

25. Hajnal, G., 'Public Sector Reform in Hungary: Views and Experiences from Senior Executives', Country Report as part of the COCOPS Research Project, May 2013, [Online] available at http://www.cocops.eu/wp-content/uploads/2013/10/Hungary-WP3.pdf, accessed on August 30, 2017.

26. Hall, R., 'Outsourcing, Contracting-out and Labour Hire: Implications for Human Resource Development in Australian Organizations', 2000, Asia Pacific Journal of Human Resources, vol. 38, no. 2, pp. 23-41.

27. Jimenez, B.S., 'Raise Taxes, Cut Services, or Lay off Staff: Citizens in the Fiscal Retrenchment Process', Journal of Public Administration Research and Theory, 2013, vol. 24, no. 4, pp. 923-953.

28. Jimenez, B.S., 'Institutional Constraints, Rule-Following, and Circumvention: Tax and Expenditure Limits and the Choice of Fiscal Tools During a Budget Crisis', 2017, Public Budgeting E Finance, vol. 37, no. 2, pp. 5-34.

29. Kim, Y. and Warner, M. E., 'Pragmatic Municipalism: Local Government Service Delivery After the Great Recession', 2016, Public Administration, vol. 94, no. 3, pp. 789-805.

30. Ladi, S. and Tsarouhas, D., 'The Politics of Austerity and Public Policy Reform in the EU', 2014, Political Studies Review, vol. 12, no. 2, pp. 171-180.

31. Lawrence, P.R. and Lorsch, J.W., 'Differentiation and Integration in Complex Organizations', 1967, Administrative Science Quarterly, vol. 12, no. 1, pp. 1-47. 
32. Levine, C.H., Rubin, I.S. and Wolohojian, G.G., The Politics of Retrenchment: How Local Governments Manage Fiscal Stress, Beverly Hills, CA: Sage Publications, 1981.

33. Lewis, G.B., 'The Consequences of Fiscal Stress: Cutback Management and Municipal Employment', 1988, State \& Local Government Review, vol. 20, no. 2, pp. 64-71.

34. Lobao, L.M. and Adua, L., 'State Rescaling and Local Governments' Austerity Policies Across the USA, 2001-2008', 2011, Cambridge Journal of Regions, Economy and Society, vol. 4, no. 3, pp. 419-435.

35. Lobao, L.M., Adua, L. and Hooks, G., 'Privatization, Business Attraction, and Social Services across the United States: Local Governments' Use of Market-Oriented, Neoliberal Policies in the Post-2000 Period', Social Problems, vol. 61, no. 4, pp. 644-672.

36. López-Hernández, A.M., Zafra-Gómez, J.L., Plata-Díaz, A.M. and de la Higuera-Molina, E.J., 'Modeling Fiscal Stress and Contracting Out in Local Government: The Influence of Time, Financial Condition, and the Great Recession', 2018, The American Review of Public Administration, vol. 48, no. 6, pp. 565-583.

37. Lu, J., 'How Political are Government Contracting Decisions? An Examination of Human Service Contracting Determinants', 2013, Public Administration Quarterly, vol. 37, no. 2, pp. 183-209.

38. Maher, C.S. and Deller, S.C., 'Municipal Responses to Fiscal Stress', International Journal of Public Administration, vol. 30, no. 12-14, pp. 1549-1572.

39. McDonough, J.E., 'Budget Sequestration and the US Health Sector', 2013, New England Journal of Medicine, vol. 368, no. 14, pp. 1269-1271.

40. Niskanen, W.A., Bureaucracy and Representative Government, Chicago, IL: Transaction Publishers, 1971.

41. Piatak, J.S., 'Weathering the Storm: The Impact of Cutbacks on Public Employees', 2018, Public Personnel Management, vol. 48, no. 1, pp. 97-119.

42. Pynes, J., 'Strategic Human Resources Management', in Hays, S.W. and Kearney, R.C. (eds.), Public Personnel Administration: Problems and Prospects, $5^{\text {th }}$ edition, Upper Saddle River, NJ: Prentice Hall, 2003, pp. 95-106.

43. Pynes, J.E., Human Resources Management for Public and Nonprofit Organizations: A Strategic Approach, Hoboken, NJ: John Wiley \& Sons, 2008.

44. Radin, B., Federal Management Reform in A World of Contradictions, Washington, DC: Georgetown University Press, 2012.

45. Scanlon, E. and Harding, S., 'Social Work and Labor Unions: Historical and Contemporary Alliances', 2005, Journal of Community Practice, vol. 13, no. 1, pp. 9-30.

46. Stein, L., 'Privatization, Work-Force Cutbacks, and African-American Municipal Employment', 1994, The American Review of Public Administration, vol. 24, no. 2, pp. 181-191.

47. Stone, S.B., Singla, A., Comeaux, J. and Kirschner, C., 'A Comparison of Financial Indicators: The Case of Detroit', 2015, Public Budgeting $\mathcal{E}$ Finance, vol. 35, no. 4, pp. 90-111.

48. Sun, J., 'Budget Strategy: A Survey of California County Governments', 2010, California Journal of Politics and Policy, vol. 2, no. 1, pp. 1-20.

49. Walls, M., Macauley, M. and Anderson, S., 'Private Markets, Contracts, and Government Provision: What Explains the Organization of Local Waste and Recycling Markets?', 2005, Urban Affairs Review, vol. 40, no. 5, pp. 590-613.

50. Warner, M. and Hebdon, R., 'Local Government Restructuring: Privatization and Its Alternatives', 2001, Journal of Policy Analysis and Management, vol. 20, no. 2, pp. 315-336. 
51. West, J. and Condrey, S., 'Municipal Government Strategies for Controlling Personnel Costs during the Fiscal Storm', 2010, Journal of Public Budgeting, Accounting and Financial Management, vol. 23, no. 3, pp. 395-426.

52. Williams, J.C., 'The Constitutional Vulnerability of American Local Government: The Politics of City Status in American Law', 1986, Wisconsin Law Review, pp. 83-154.

53. Williamson, O.E., 'The Economics of Organization: The Transaction Cost Approach', 1981, American Journal of Sociology, vol. 87, no. 3, pp. 548-577.

54. Zafra-Gómez, J.L., Plata-Díaz, A.M., Pérez-López, G. and López-Hernández, A.M., 'Privatisation of Waste Collection Services in Response to Fiscal Stress in Times of Crisis', 2016, Urban Studies, vol. 53, no. 10, pp. 2134-2153. 


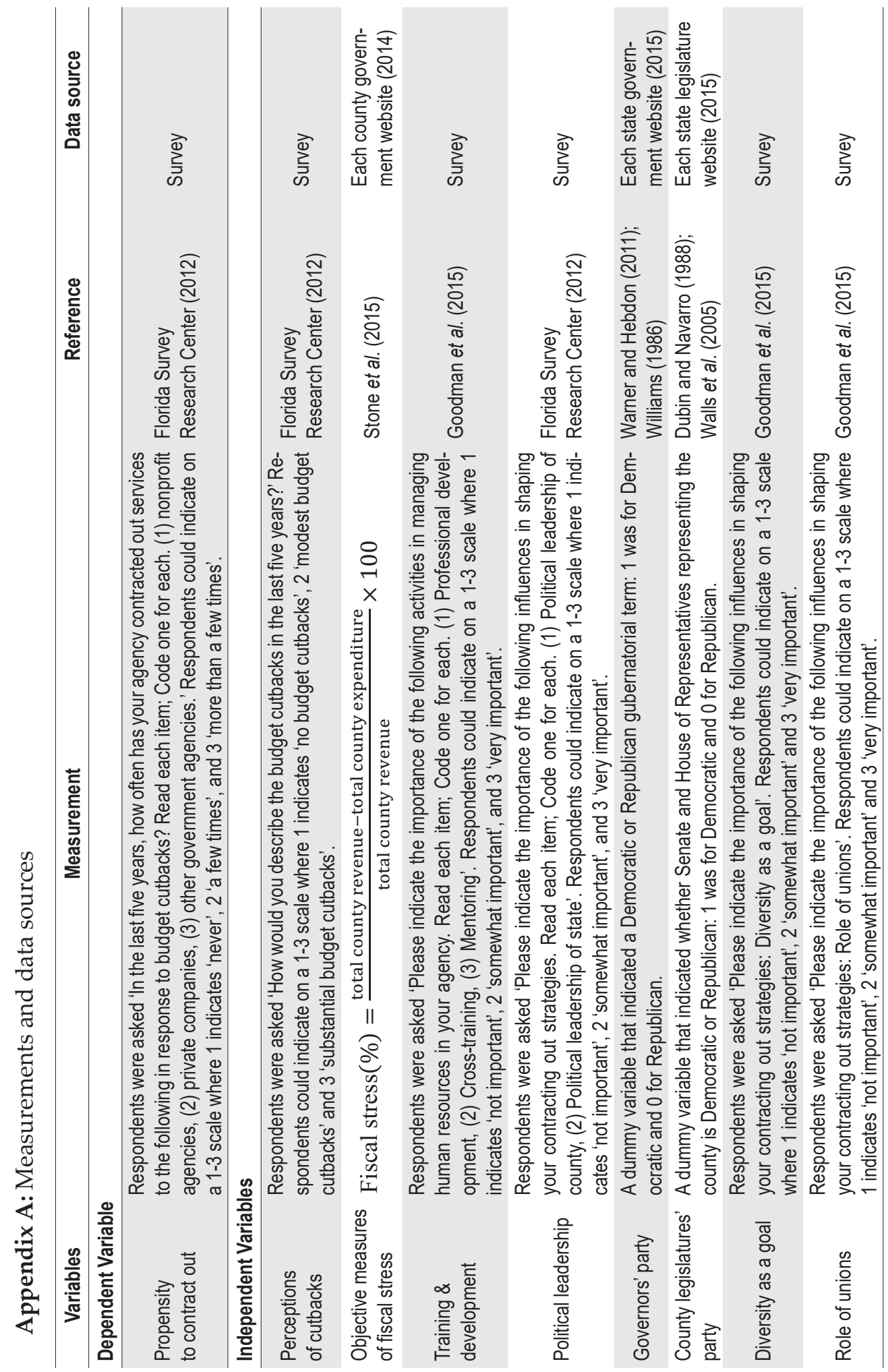




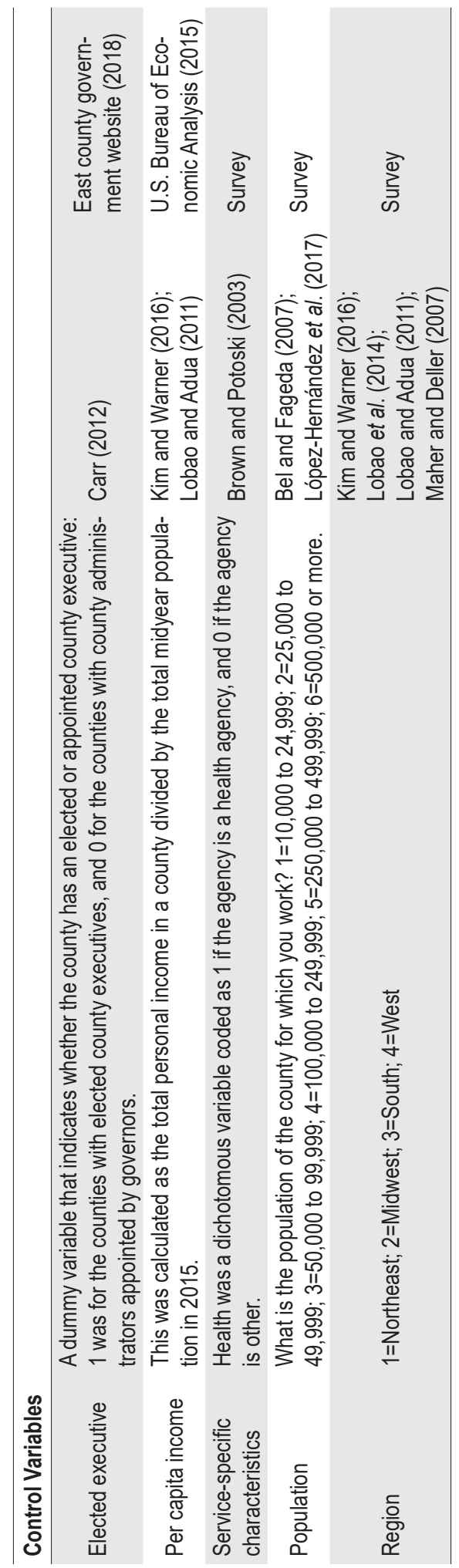


Appendix B: Importance of functions and activities

\begin{tabular}{lcccc}
\hline Importance of these functions and activities & & & & \\
\hline Training \& development & $\begin{array}{c}\text { Very } \\
\text { Important \% }\end{array}$ & $\begin{array}{c}\text { Somewhat } \\
\text { Important \% }\end{array}$ & Not Important \% & Mean \\
\hline Professional development & 82.90 & 17.10 & 0.00 & 2.83 \\
\hline Cross-training & 72.54 & 25.13 & 2.33 & 2.70 \\
\hline Mentoring & 58.29 & 37.82 & 3.89 & 2.54 \\
N=386; Index: mean 2.69, Cronbach's a $=0.55$ & & & & \\
County political leadership & 51.55 & 36.01 & 12.44 & 2.39 \\
\hline State political leadership & 45.08 & 39.12 & 15.80 & 2.29 \\
\hline Diversity as a goal & 42.49 & 46.89 & 10.62 & 2.32 \\
\hline Role of unions & 11.40 & 25.39 & 63.21 & 1.48 \\
\hline
\end{tabular}

